\title{
The late gestation increase in circulating ACTH and cortisol in the fetal sheep is suppressed by intracerebroventricular infusion of recombinant ovine leptin
}

\author{
D C Howe, A Gertler ${ }^{1}$ and J R G Challis ${ }^{2}$ \\ Department of Obstetrics and Gynaecology, The Queen Mother's Hospital, Yorkhill, Glasgow G3 8SJ, UK \\ ${ }^{1}$ Department of Agricultural and Food Science, Hebrew University of Jerusalem, Israel \\ ${ }^{2} \mathrm{CIHR}$ Group in Fetal and Neonatal Health and Development, Departments of Physiology, Obstetrics and Gynaecology, University of Toronto, \\ Toronto, Canada \\ (Requests for offprints should be addressed to D Howe; Email: HOWEdavidc@aol.com)
}

\begin{abstract}
The obese gene product leptin, originally characterised as an adipocyte hormone coordinating the behavioural and neuroendocrine responses to starvation, is expressed in fetal adipocytes and placental trophoblast cells and is present in the fetal circulation. Concentrations of leptin in fetal blood correlate with fetal bodyweight and fat mass. In post-natal life, leptin conveys information about calorie intake and the state of adipose tissue energy stores, and plasma leptin levels are generally inversely correlated with hypothalamo-pituitary adrenal (HPA) activity. Late fetal life is characterised by increasing HPA activity that prepares the fetus for extrauterine life and initiates the
\end{abstract}

endocrine cascade leading to parturition. We have investigated the hypothesis that leptin in the fetal circulation can inhibit the fetal HPA axis, thereby providing a mechanism by which the fetus can determine the fine timing of parturition as long as it is adequately nourished and growing appropriately. Here we show that a 5-day intracerebroventricular infusion of leptin to the sheep fetus in late gestation inhibits the pre-parturient rise in ACTH and cortisol concentrations, and that this seems to be a centrally mediated effect.

Journal of Endocrinology (2002) 174, 259-266

\section{Introduction}

The obese gene product leptin is present in the fetal circulation, and is expressed in fetal adipocytes (Yuen et al. 1999) and placental trophoblast cells (Hoggard et al. 1997, Henson et al. 1998, 1999). The physiological function of leptin in the fetal circulation is unknown. One uncontrolled study in the near term sheep fetus reports that acute intracerebroventricular infusion of leptin stimulates fetal swallowing and urine flow (Roberts et al. 2001). In post-natal life, leptin is intimately concerned with coordinating the behavioural and endocrine responses to energy restriction (Rosenbaum et al. 1997, Barb et al. 1999). Feed restriction is associated with a fall in expression of leptin mRNA in adipose tissue, and a decline in circulating leptin concentrations. Infusion of leptin inhibits feeding behaviour in fasted and fed animals, increases insulin sensitivity to glucose (Ogawa et al. 1999, Shimomura et al. 1999) and prevents the fasting-induced decline in gonadotrophin secretion (Casanueva \& Dieguez 1999, Cunningham et al. 1999, Nagatani et al. 2000) and increase in adrenal corticosteroid secretion (Ahima et al.
1996). There is evidence for an interaction between leptin and the hypothalamo-pituitary adrenal (HPA) axis (Casanueva \& Dieguez 1999). Corticosteroids increase leptin expression in cultured adipocytes (Russell et al. 1998). Infusion of leptin inhibits fasting- and stressinduced increases in corticosterone (Ahima et al. 1996, Heiman et al. 1997) and, whereas leptin is a satiety signal, corticosteroids generally stimulate appetite (Solano \& Jacobson 1999, Wooldridge et al. 2001).

In late gestation, increasing activity of the fetal HPA axis is crucial for initiating events that lead to birth and for fetal preparation for extrauterine life (Challis et al. 2000). The mechanisms driving the increase in fetal HPA activity are poorly understood. Metabolic signals related to the ability to sustain fetal growth may be important. In a sense, all fetal growth is metabolically constrained (Vatnick et al. 1991, Gluckman et al. 1992) and increasing fetal size in late gestation places greater demands on maternal metabolism and transplacental transfer of nutrients (Schneider 1996). Poor maternal weight gain, fetal growth restriction and maternal fasting have all been identified as factors associated with premature delivery in humans and 
domestic species (Silver 1990, Ott 1993, Hediger et al. 1995, McMillen et al. 1995). Cord blood concentrations of leptin correlate with birthweight and fat mass (Jaquet et al. 1998, Geary et al. 1999), suggesting that leptin might signal information to the fetal HPA axis about fetal metabolic status. A fetus that is relatively well supplied with metabolic substrate for continued growth would be expected to have a higher plasma leptin concentration that in turn will inhibit the fetal HPA axis and delay parturition.

We hypothesised that leptin would suppress the fetal HPA axis in utero. Accordingly, we have investigated the effects of $120 \mathrm{~h}$ continuous intracerebroventricular infusion of recombinant ovine leptin on HPA axis activity in the late gestation sheep fetus. Fetuses were challenged with corticotrophin-releasing hormone (CRH) and vasopressin (AVP) to determine pituitary sensitivity after $96 \mathrm{~h}$ of leptin infusion. Intravenous glucose tolerance tests were administered to the fetuses to determine whether leptin infusion led to altered insulin resistance in the fetus.

\section{Materials and Methods}

\section{Animals}

Fetuses of time-mated mixed breed sheep were prepared with jugular, carotid and lateral ventricle cannulae on day 125-130 gestation (term $145 \pm 2$ ) as previously described (Challis et al. 1981). Vascular catheters were flushed daily with heparinised saline and fetal acid-base status and blood gases were monitored on a daily basis. Ewes were provided with food and water and allowed to feed ad libitum. They were housed in rooms with a $12 \mathrm{~h}$ light: $12 \mathrm{~h}$ darkness cycle. The day before the start of the infusion period, ewes were placed into individual metabolism crates allowing limited forwards and backwards movement. The study was performed using protocols approved by the University of Toronto, Animal Study Review Board, according to the Guidelines of the Canadian Council for Animal Care (CCAC).

\section{Leptin treatment}

Fetuses received a continuous intracerebroventricular infusion of $20 \mu \mathrm{g} / \mathrm{h}$ recombinant ovine leptin (Gertler et al. 1998) $(n=6)$ or cerebrospinal fluid vehicle $(n=4)$ from day 135 to 140 gestation, infused at a rate of $120 \mu \mathrm{l} / \mathrm{h}$.

\section{Basal hormone secretion and challenge tests}

Basal hormone secretion was assessed over a 4-h period starting at $0800 \mathrm{~h}$ on day 135 and again on day 140 after $120 \mathrm{~h}$ continuous infusion of intracerebroventricular leptin or vehicle. Samples $(1 \mathrm{ml})$ were withdrawn every $10 \mathrm{~min}$ from the fetal carotid artery and volume replaced with heparinised saline. On both days at the end of the 4-h basal sampling period, a $4 \mathrm{~g}$ intravenous glucose challenge was given directly to the fetus and further blood samples withdrawn at 10, 20, 30, 60, 90 and $120 \mathrm{~min}$. Arterial blood gases and haematocrit were monitored hourly during the sampling period. Additional daily samples were withdrawn at 0800,1400 and $2200 \mathrm{~h}$ throughout the experiment. A pituitary challenge with $4 \mu \mathrm{g} \mathrm{CRH}+4 \mu \mathrm{g}$ AVP was administered at $0800 \mathrm{~h}$ on the morning of day 139 after $96 \mathrm{~h}$ continuous intracerebroventricular infusion of leptin or vehicle. Blood samples were separated immediately and plasma stored at $-70{ }^{\circ} \mathrm{C}$ until analysis.

\section{Hormone assays}

Plasma concentrations of adrenocorticotrophin (ACTH) were measured by a commercially available radioimmunoassay kit (Diasorin, Stillwater, MN, USA) as previously described (Norman et al. 1985). Intra-assay and interassay coefficients of variation were $8 \%$ and $12 \%$ respectively, and the assay limit of sensitivity was $6 \mathrm{pg} / \mathrm{ml}$. Cortisol was measured after extraction with diethyl ether (Challis et al. 1981). Intra-assay and interassay coefficients of variation were $9 \%$ and $12 \%$ respectively. Plasma leptin concentration was measured by kit (multispecies leptin assay, Linco Research, St Charles, MO, USA) using recombinant ovine leptin standards. This kit has previously been reported to detect ovine leptin (Delavaud et al. 2000, Ehrhardt et al. 2000). The combined intra- and interassay coefficient of variation was $8 \%$ and the assay limit of sensitivity was $1 \mathrm{ng} / \mathrm{ml}$ of recombinant ovine standard. Plasma insulin concentration was determined by kit (Linco, rat insulin) using rat insulin as standard. The combined intra- and interassay coefficient of variation was $8 \%$ and the assay limit of sensitivity $0.2 \mathrm{ng} / \mathrm{ml}$. Glucose was determined by glucometer (Glucometer Elite, Bayer Inc., Ontario, Canada). The combined intra- and interassay coefficient of variation on pooled fetal plasma was $3 \%$.

\section{Statistical analysis}

Values are presented as means \pm S.E.M. for the number of animals studied. Individual profiles of ACTH and cortisol were analysed for pulsatile secretion using the Munro program (Skinner et al. 1995). Briefly, a rolling average of local nadirs is used to create a baseline from which pulses are detected as deviations of at least three standard deviations. Mean baseline, pulse amplitude, interpulse interval and average hormone concentrations were calculated for each animal before and at the end of the leptin infusion. Systematic differences between the groups were determined by analysis of the variance with post hoc $t$-test. The significance level was set at 5\%. For pituitary and glucose challenge tests, basal, peak response and area under the curve were calculated and compared. 

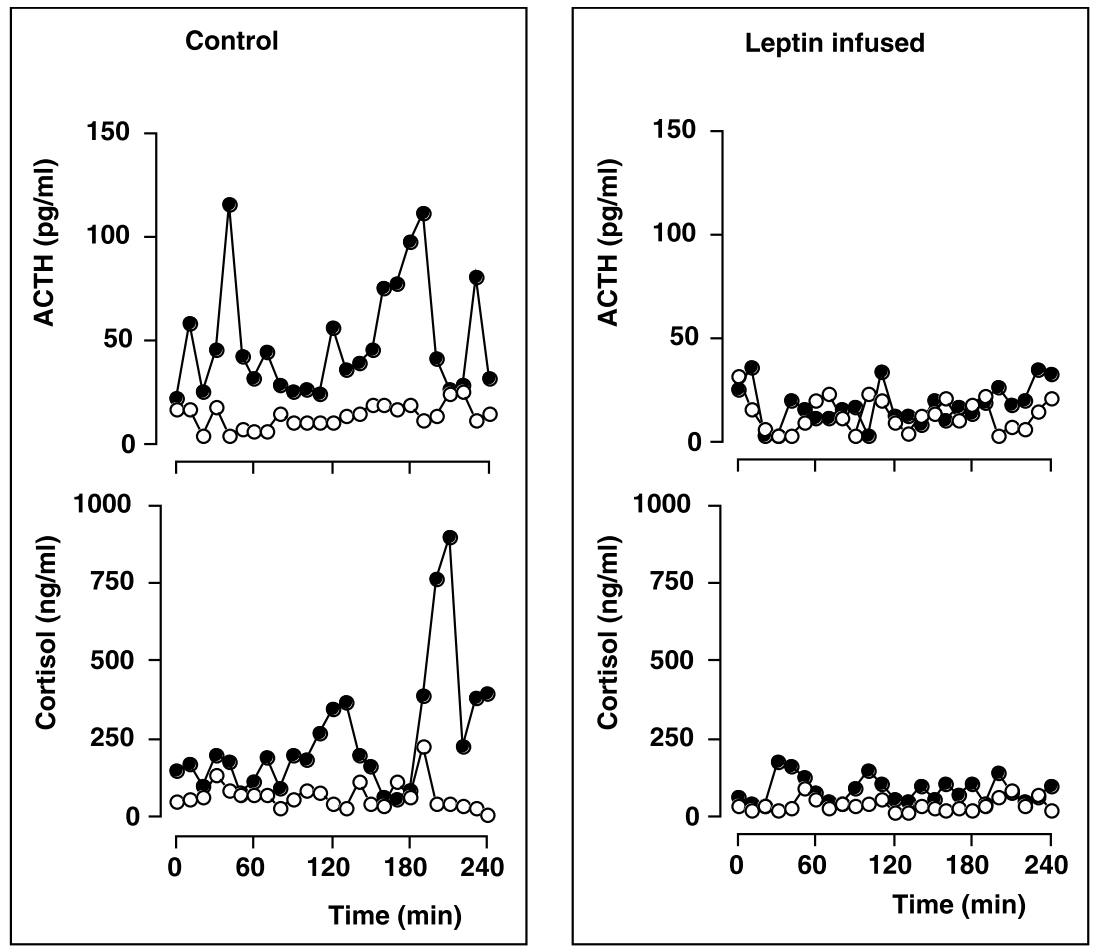

Figure 1 Montage showing ACTH (upper panels) and cortisol (lower panels) concentrations in two representative fetuses receiving an intracerebroventricular infusion of either vehicle (left-hand panel) or leptin (right-hand panel) for 5 days from day 135 to day 140 gestation. Hormone concentrations during the 4-h sampling period on day 135 are shown as open circles and during repeat sampling on day 140 as filled circles.

\section{Results}

Effect of leptin on basal HPA axis activity

Basal ACTH and cortisol concentrations were assessed on the morning of day 135 of gestation (prior to commencing intracerebroventricular infusion of recombinant leptin or vehicle) and again on the morning of day 140 (after 5 days of continuous treatment). The profiles of ACTH and cortisol concentrations in two representative fetuses are shown in Fig. 1.

The concentrations of both hormones in samples withdrawn every 10 min during a 4 -h period between 0800 and $1200 \mathrm{~h}$ on days 135 and 140 were subjected to pulse analysis (Skinner et al. 1995). Figure 2 shows pulse amplitude, basal (nadir) and mean concentrations for ACTH and cortisol. Pulses of ACTH, detected as deviations from local baseline (the average of all local minima over a 60-min epoch) of more than three assay coefficients of variation, increased in amplitude between day 135 and day 140 in control fetuses. Basal (nadir) concentrations also increased, but there was no change in pulse frequency. At day 140, leptin infusion significantly abrogated the increase in ACTH pulse amplitude (ANOVA, treatment by time interaction: $P<0 \cdot 01)$ and basal and mean $\mathrm{ACTH}$ concentrations were reduced significantly. Pulse frequency was unchanged by leptin treatment. Similarly, the gestation-dependent increases in pulse amplitude, basal and mean cortisol concentrations were significantly less in leptin-treated fetuses at day 140 compared with control fetuses (ANOVA, treatment by time interaction: $P<0 \cdot 01$ ).

\section{Effect of leptin on pituitary sensitivity to CRH and AVP}

The ACTH response (peak ACTH concentration and area under curve) to a bolus injection of $\mathrm{CRH}$ and AVP given after $96 \mathrm{~h}$ of continuous leptin infusion was not significantly different from that of control fetuses (Fig. 3) (ANOVA, main effect of treatment: P>0.05). Basal ACTH prior to $\mathrm{CRH}$ and AVP challenge was significantly lower in the leptin-infused fetuses (ANOVA, main effect of treatment: $P<0 \cdot 01)$. Basal cortisol concentrations were lower in the leptin-treated fetuses, but the adrenal response to CRH and AVP challenge (peak cortisol and area under the curve) did not differ between groups (ANOVA, $P<0 \cdot 01$ ).

Effect of leptin on glucose homeostasis

Plasma glucose and insulin concentrations following $1 \mathrm{~g} / \mathrm{kg}$ fetal intravenous glucose challenge are shown in 

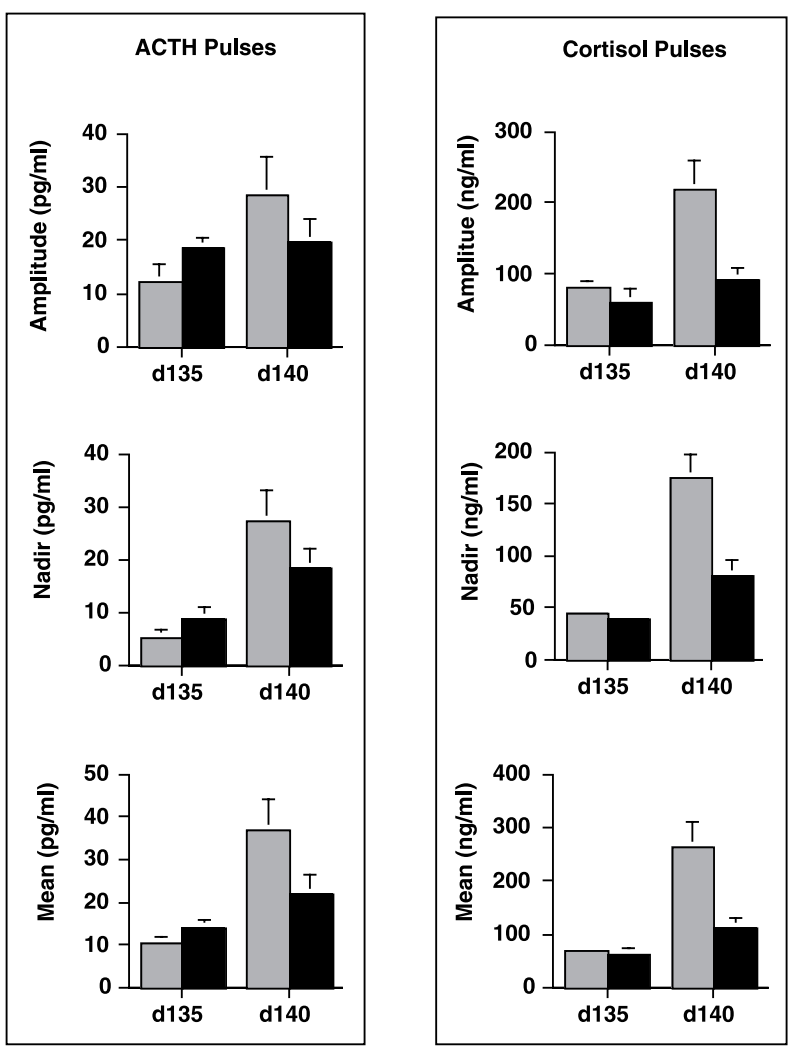

Figure 2 Summary of pulse analysis of plasma ACTH and cortisol concentrations during the 4-h sampling period on day 135 before, and on day 140 after 5 days of continuous intracerebroventricular infusion of vehicle (stippled bars) or leptin (solid bars). Pulse amplitude, nadir and mean hormone concentration are shown in upper, middle and lower panels respectively. Values are means \pm S.E.M. ACTH and cortisol pulse amplitude, nadir (baseline) and mean concentration increased from day 135 to 140 . The rise in amplitude, nadir and mean concentration was significantly less in leptin-infused fetuses (ANOVA: treatment by time interaction, $P<0 \cdot 01)$.

Fig. 4. Intracerebroventricular leptin infusion had no effect on basal glucose or insulin concentrations. Following intravenous glucose challenge, plasma insulin concentrations peaked with an approximate 20-min lag on peak glucose concentrations. There were no significant differences between groups in glucose or insulin peak or area under the insulin curve, or in the regression of peak insulin on peak glucose. There was no change in ACTH or cortisol concentrations during the glucose challenge.

\section{Plasma leptin concentrations}

Plasma leptin concentration was below the assay limit of sensitivity from 135 to 140 days in control fetuses, but was detected in the plasma of all leptin-infused fetuses (Fig. 5).
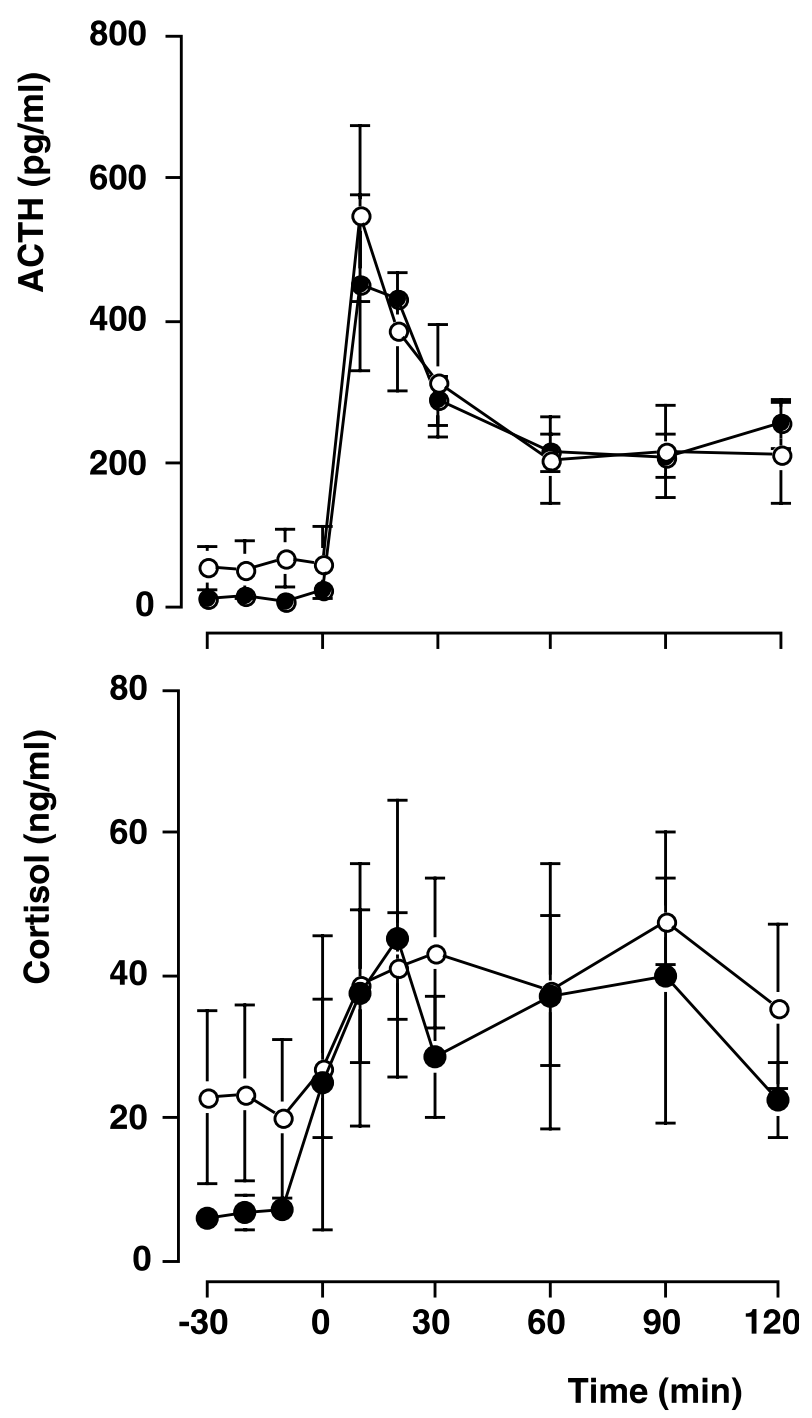

Figure 3 Plasma ACTH (upper panel) and cortisol (lower panel) concentrations after challenge with $4 \mu \mathrm{g}$ corticotrophin releasing hormone and $4 \mu \mathrm{g}$ vasopressin after $96 \mathrm{~h}$ of continuous intracerebroventricular infusion of vehicle $(\bigcirc)$ or leptin Values are means \pm S.E.M.

\section{Discussion}

We hypothesised that exogenous leptin would suppress the fetal HPA axis in late gestation. Our results demonstrate that continuous intracerebroventricular infusion of recombinant ovine leptin for 5 days abrogated the normal rise in plasma ACTH and cortisol concentrations that occur prior to parturition in the near term fetal sheep. Leptin infusion, however, despite elevating peripheral leptin concentrations and lowering cortisol, did not alter basal glucose or insulin concentrations. Similarly, the insulin response and glucose clearance after intravenous glucose challenge did not differ. 


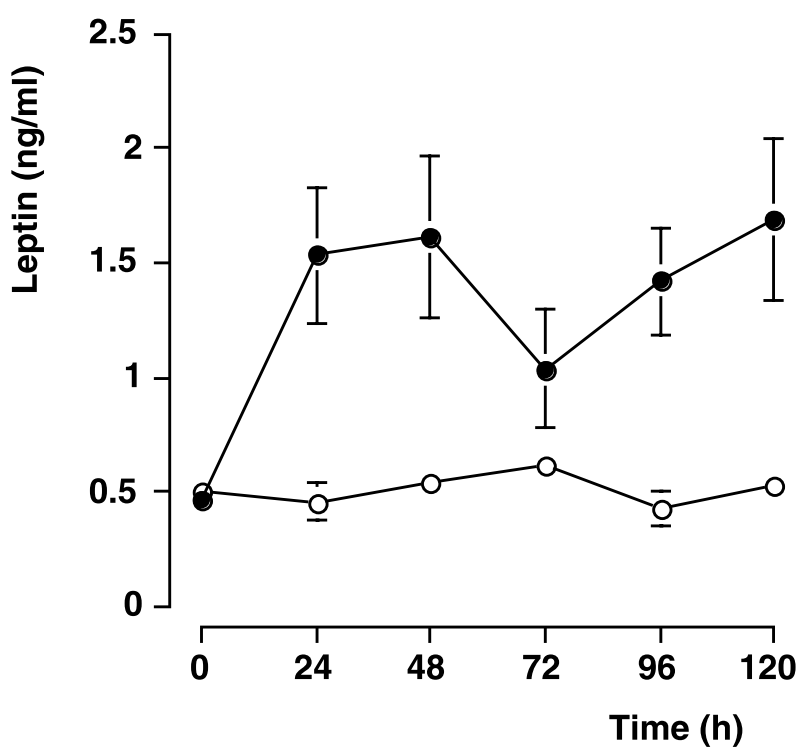

Figure 4 Daily leptin concentrations in fetal plasma during intracerebroventricular infusion of vehicle $(O)$ or recombinant ovine leptin $(\mathbf{O})$. Values are means \pm S.E.M. Plasma leptin was significantly elevated by $24 \mathrm{~h}$ in fetuses receiving intracerebroventricular infusion of leptin, and remained elevated throughout the infusion.
In these experiments, leptin was administered intracerebroventricularly in order to achieve a significant elevation of leptin in the vicinity of the hypothalamic nuclei. Subsequently, the drainage of cerebrospinal fluid through lymphatics and arachnoid granulations allowed centrally administered leptin to enter the systemic circulation, as has been shown for other peptides (Mollanji et al. 2001). Infusing recombinant ovine leptin at a rate of $20 \mu \mathrm{g} / \mathrm{h}$ intracerebroventricularly, we have achieved plasma levels of leptin similar to those reported in adult sheep (Blache et al. 2000, Delavaud et al. 2000, Ehrhardt et al. 2000, Nagatani et al. 2000, Morrison et al. 2001, Thomas et al. 2001). Plasma leptin concentrations in the near term sheep fetus have been reported in the range of $400 \mathrm{pg} / \mathrm{ml}$ (Buchbinder et al. 2001, Forhead et al. 2002), unfortunately below the detection limit of the assay we have used. The leptin concentration achieved in the peripheral circulation in the treated fetuses is increased around three- to fourfold above that expected in control fetuses. Elevations of leptin in response to acute rises in cortisol, for example in association with hypoxaemia, however, might achieve similar high plasma concentrations. Nonetheless, actual hypothalamic levels may not be elevated to the same magnitude. Intracerebroventricularly administered leptin penetrates adjacent brain
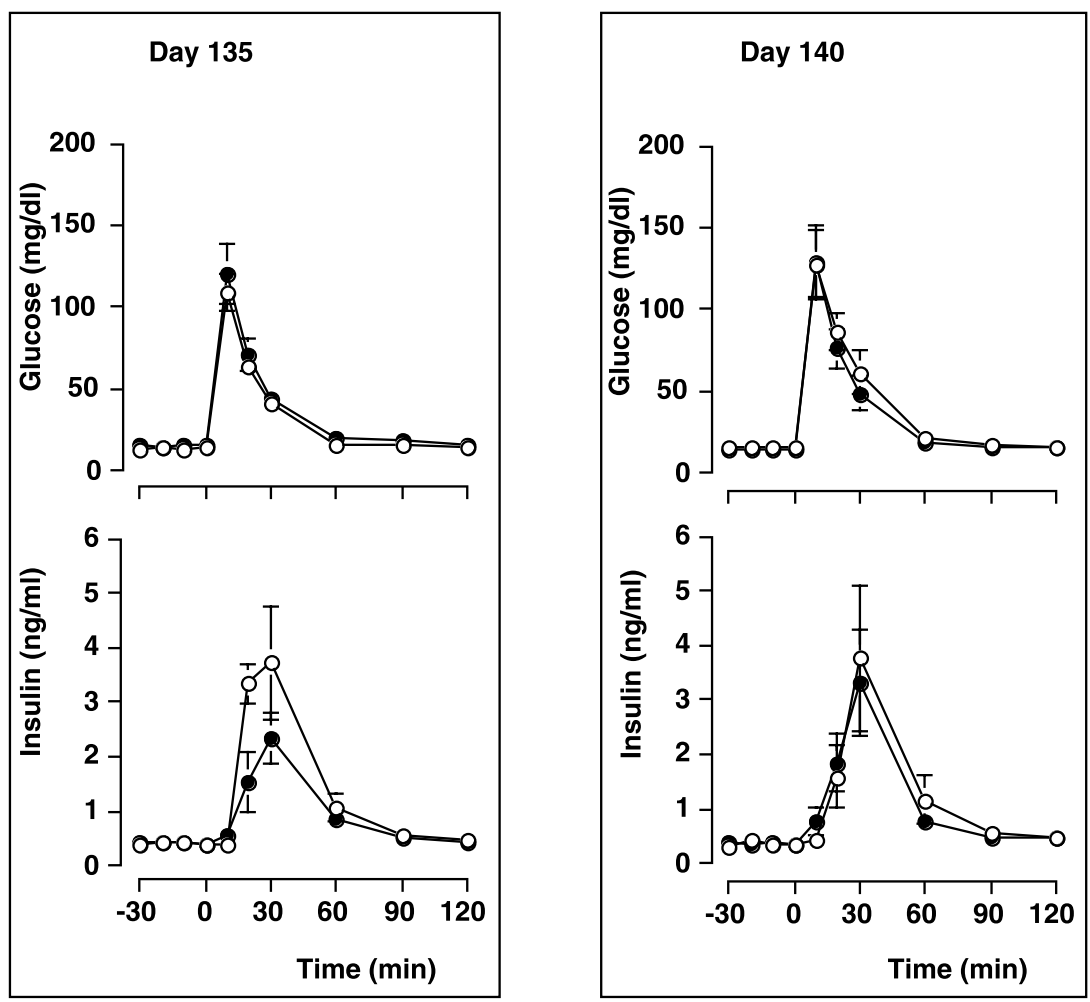

Figure 5 Plasma glucose (upper panels) and insulin (lower panels) during intravenous glucose challenge ( $4 \mathrm{~g}$ ) on day 135 (left panel) and day 140 gestation (right panel). Hormone concentrations in fetuses receiving intracerebroventricular infusion of vehicle are shown as open circles and leptin as filled circles. Values are means \pm S.E.M. 
parenchyma poorly (Maness et al. 1998). Furthermore, transport of circulating leptin across the blood-brain barrier seems to be saturable (Ramsey et al. 1998), such that there is a 100- to 200-fold difference between plasma and cerebrospinal fluid concentrations (Dotsch et al. 1997, Blache et al. 2000).

Despite significant elevations of peripheral leptin and a decrease in cortisol, we found no change in basal glucose or insulin concentrations. As shown previously, fetal insulin responses were monophasic (Philipps et al. 1978). The glucose clearance and insulin response to glucose challenge did not change with gestation or leptin treatment. Leptin has been reported both to increase and decrease skeletal muscle sensitivity to insulin in rodents (Sweeney et al. 2001, Yaspelkis et al. 2001). In culture, high doses of leptin markedly reduced insulin-stimulated glucose uptake (Sweeney et al. 2001). In rodents, leptin also increases insulin sensitivity to glucose (Ogawa et al. 1999, Shimomura et al. 1999) and glucose disposal (Kamohara et al. 1997) by increasing uptake into brown adipose tissue. However, fetal brown adipose tissue is functionally immature until shortly before birth. Others find that in adult sheep, infusion of leptin had no effect on basal plasma insulin levels (Morrison et al. 2001).

In the fetal sheep, we found that exogenous leptin inhibits the HPA axis. The activation of fetal HPA activity in late gestation is well characterised and the increase in mean ACTH and cortisol concentrations in control fetuses is in agreement with previous reports. The amplitude and frequency of ACTH and cortisol pulse are in the range previously reported by others (Brooks \& Challis 1991, Apostolakis et al. 1992, Canny et al. 1998), but we found an increase in ACTH and cortisol pulse amplitude from day 135 to day 140 . Others examining the period 140-142 days could not demonstrate a change in pulsatile ACTH or cortisol characteristics (Apostolakis et al. 1992). We found that intracerebroventricular infusion of leptin at a rate similar to that used in adult sheep (Henry et al. 1999) results in a blunting of the normal pre-parturient rise in mean ACTH and cortisol concentrations. This is a consequence of a reduction in pulse amplitude rather than a decrease in pulse frequency. The effect is likely to be centrally mediated since the pituitary response to challenge with AVP and CRH did not differ between treated and control fetuses.

The observation that exogenous leptin inhibits the fetal HPA axis is consistent with findings in rodents where leptin blocks the adrenocortical response to fasting (Ahima et al. 1996) and stress activation of HPA function (Heiman et al. 1997). The effects of leptin on the neuroendocrine axis in larger animals have been questioned. In one study in ovariectomised adult ewes, recombinant human leptin infused intracerebroventricularly at a rate of $20 \mu \mathrm{g} / \mathrm{h}$ for $72 \mathrm{~h}$ reduced food intake, but did not alter pulsatile luteinising hormone (LH) or growth hormone (GH) secretion (Henry et al. 1999). Pooled plasma cortisol, follicle-stimulating hormone (FSH) and prolactin (PRL) also remained unchanged. Control animals did not have their dietary intake reduced to match that of the treated group, so that it is impossible to assess if leptin inhibited neuroendocrine responses to energy restriction. In another study of oestrogen-treated castrated males, subcutaneous recombinant human leptin $(150 \mu \mathrm{g} / \mathrm{kg}$ per day) achieving plasma levels of $18 \mathrm{ng} / \mathrm{ml}$ (in comparison with endogenous plasma levels of $1-2 \mathrm{ng} / \mathrm{ml}$ ) prevented the decline in $\mathrm{LH}$ pulse frequency during a 78-h fast, and at the same time increased the amplitude of GH pulses (Nagatani et al. 2000). In long-term feed-restricted adult sheep, intracerebroventricular infusion of leptin increases GH concentrations (Henry et al. 2001, Morrison et al. 2001). The reported effects on the reproductive axis conflict with studies finding either no change (Morrison et al. 2001) or an increase in LH pulse frequency (Henry et al. 2001). There is a paucity of literature on the HPA axis and leptin under such conditions.

The fetus differs from the adult in a number of ways and might not be expected to respond to leptin in the same way as an adult. Nutrient intake cannot be increased by stimulation of feeding behaviour. Fetal growth is metabolically constrained and provision of extra calories either by direct intrafetal infusion of glucose, by maternal overnutrition or insulin-like growth factor-I (IGF-I) treatment promotes fetal somatic growth rather than accumulation of fat stores (Charlton \& Johengen 1987, Stevens et al. 1990, Stephenson et al. 2001). The fetus is relatively lean and there seem to be endocrine mechanisms inhibiting energy accumulation as adipose tissue (Hay 1995). Leptin is present both in fetal adipose tissue and the placenta in the sheep (Thomas et al. 2001) as in other species (Hoggard et al. 1997, Henson et al. 1998, 1999, Chen et al. 2000). The expression of leptin in perirenal adipocytes in the fetal sheep increases with gestation (Yuen et al. 1999). However, the proportion of perirenal fat in comparison with fetal body weight declines in late gestation (Hay 1995, Stephenson et al. 2001) and the relative contributions of placental and adipose tissue to circulating leptin concentrations are unknown. It is unlikely, however, that plasma leptin concentrations convey information solely about the state of fetal adipose stores.

In adults, the disproportionate change in leptin in proportion to fat mass following weight reduction or acute overfeeding has led to the suggestion that leptin signals caloric intake rather than fat mass per se (Considine et al. 1996, Kolaczynski et al. 1996, Barb et al. 1999). Regardless of whether fetal plasma leptin levels are determined by calorie intake or by some more complex interaction of placental and adipose tissue growth, we show that increases in circulating leptin have the potential to inhibit the fetal HPA axis in late gestation. We speculate that the functional consequences of this may be to prevent the accelerated fetal HPA activation that leads to parturition and to promote continued fetal growth. Infusion of cortisol 
into adrenalectomised fetuses to mimic the normal pre-parturient increase in cortisol inhibits fetal growth (Fowden et al. 1996). A fetus receiving adequate metabolic substrate via the placenta might be expected to maintain relatively higher plasma leptin concentrations, that in turn suppress the fetal HPA axis, thereby allowing continued growth and postponing birth. Removal of that leptin-imposed inhibition in late pregnancy might then contribute to activation of fetal HPA function and parturition.

\section{Acknowledgements}

We thank the staff of the Division of Comparative Medicine at the University of Toronto, and Alison Holloway and David Cox for expert technical assistance. DH was in receipt of a SHERT travelling fellowship.

\section{References}

Ahima RS, Prabakaran D, Mantzoros C, Qu DQ, Lowell B, Maratosflier E \& Flier JS 1996 Role of leptin in the neuroendocrine response to fasting. Nature 382 250-252.

Apostolakis EM, Longo LD, Veldhuis JD \& Yellon SM 1992 Dissociation of pulsatile cortisol and adrenocorticotropin secretion in fetal sheep during late gestation. Endocrinology 130 2571-2578.

Barb CR, Barrett JB, Kraeling RR \& Ranpacek GB 1999 Role of leptin in modulating neuroendocrine function: a metabolic link between the brain-pituitary and adipose tissue. Reproduction in Domestic Animals 34 111-125.

Blache D, Tellam RL, Chagas LM, Blackberry MA, Vercoe PE \& Martin GB 2000 Level of nutrition affects leptin concentrations in plasma and cerebrospinal fluid in sheep. Journal of Endocrinology 165 625-637.

Brooks AN \& Challis JRG 1991 Effects of naloxone on the preparturient increase in adrenocorticotrophin and cortisol in foetal sheep. Journal of Neuroendocrinology 3 419-424.

Buchbinder A, Friedman A, Baker RS \& Clark KE 2001 Glucose regulates maternal and fetal leptin levels. Journal of the Society for Gynecological Investigation 8 (Suppl 1) 268A, Abstract 752.

Canny BJ, Young IR \& Veldhuis JD 1998 Hypothalamo-pituitary disconnection of the late-gestation ovine fetus results in profound changes in cortisol secretion that are not reflected in commensurate changes in adrenocorticotropin secretion. Endocrinology 139 $3210-3219$

Casanueva FF \& Dieguez C 1999 Neuroendocrine regulation and actions of leptin. Frontiers in Neuroendocrinology 20 317-363.

Challis JRG, Patrick JE, Cross J, Workewych J, Manchester E \& Power S 1981 Short-term fluctuations in the concentration of cortisol and progesterone in fetal plasma, maternal plasma, and amniotic and allantoic fluids from sheep during late pregnancy. Canadian Journal of Physiology and Pharmacology 59 261-267.

Challis JRG, Matthews SG, Gibb W \& Lye SJ 2000 Endocrine and paracrine regulation of birth at term and preterm. Endocrine Reviews 21 514-550.

Charlton V \& Johengen M 1987 Fetal intravenous nutritional supplementation ameliorates the development of embolizationinduced growth retardation in sheep. Pediatric Research 22 55-61.

Chen X, Lin J, Hausman DB, Martin RJ, Dean RG \& Hausman GJ 2000 Alterations in fetal adipose tissue leptin expression correlate with the development of adipose tissue. Biology of the Neonate $\mathbf{7 8}$ $41-47$.
Considine RV, Sinha MK, Heiman ML, Kriauciniunas A, Stephen TW, Nyce MR, Ohannesian JP, Marco CC, McKee LJ, Bauer TL \& Caro JF 1996 Serum immunoreactive-leptin concentrations in normal weight and obese humans. New England Journal of Medicine 334 292-295.

Cunningham MJ, Clifton DK \& Steiner RA 1999 Leptin's actions on the reproductive axis: perspectives and mechanisms. Biology of Reproduction 60 216-222.

Delavaud C, Bocquier F, Chilliard Y, Keisler DH, Gertler A \& Kann G 2000 Plasma leptin concentrations in ruminants: effect of nutritional status and body fatness on plasma leptin concentration assessed by a specific RIA in sheep. Journal of Endocrinology 165 519-526.

Dotsch J, Adelmann M, Englaro P, Dotsch A, Hanze J, Blum WF, Kiess W \& Rascher W 1997 Relation of leptin and neuropeptide Y in human blood and cerebrospinal fluid. Journal of Neurological Science 151 185-188.

Ehrhardt RA, Slepetis RM, Siegal-Willott J, Van Amburgh ME, Bell AW \& Boisclair YR 2000 Development of a specific radioimmunoassay to measure physiological changes of circulating leptin in cattle and sheep. Journal of Endocrinology 166 519-528.

Forhead AJ, Thomas L, Crabtree J, Hoggard N, Gardner DS, Giussani DA \& Fowden AL 2002 Plasma leptin concentrations in fetal sheep during late gestation: ontogeny and effect of glucocorticoids. Endocrinology 143 1166-1173.

Fowden AL, Szemere J, Hughes P, Gilmour RS \& Forhead AJ 1996 The effects of cortisol on the growth rate of the sheep fetus during late gestation. Journal of Endocrinology 151 97-105.

Geary M, Herschkovitz R, Pringle PJ, Rodeck CH \& Hindmarsh PC 1999 Ontogeny of serum leptin concentrations in humans. Clinical Endocrinology 51 189-192.

Gertler A, Simmons J \& Keisler DH 1998 Large-scale preparation of biologically active recombinant ovine obese protein (leptin). FEBS Letters 422 137-140.

Gluckman PD, Morel PCH, Ambler GR, Breier BH, Blair HT, McCutcheon SN 1992 Elevating maternal insulin-like growth factor-I in mice and rats alters the pattern of fetal growth by removing maternal constraint. Journal of Endocrinology 134 R1-R3.

Hay WW 1995 Current Topic: Metabolic interrelationships of placenta and fetus. Placenta 16 19-30.

Hediger ML, Scholl TO, Schall JI, Miller LW \& Fischer RL 1995 Fetal growth and the etiology of preterm delivery. Obstetrics and Gynecology 85 175-182.

Heiman ML, Ahima RS, Craft LS, Schoner B, Stephens TW \& Flier JS 1997 Leptin inhibition of the hypothalamic-pituitary-adrenal axis in response to stress. Endocrinology 138 3859-3863.

Henry BA, Goding JW, Alexander WS, Tilbrook AJ, Canny BJ, Dunshea F, Rao A, Mansell A \& Clarke IJ 1999 Central administration of leptin to ovariectomised ewes inhibits food intake without affecting the secretion of hormones from the pituitary gland: evidence for a dissociation of effects on appetite and neuroendocrine function. Endocrinology 140 1175-1182.

Henry BA, Goding JW, Tilbrook AJ, Dunshea FR \& Clark IJ 2001 Intracerebroventricular infusion of leptin elevates the secretion of luteinizing hormone without affecting food intake in long-term food restricted sheep, but increases growth hormone irrespective of bodyweight. Journal of Endocrinology 168 67-77.

Henson MC, Swan KF, O'Neil JS 1998 Expression of placental leptin and leptin receptor transcripts in early pregnancy and at term. Obstetrics and Gynecology 92 1020-1028.

Henson MC, Castracane VD, O’Neil JS, Gimpel T, Swan KF, Green AE \& Shi W 1999 Serum leptin concentrations and expression of leptin transcripts in placental trophoblast with advancing baboon pregnancy. Journal of Clinical Endocrinology and Metabolism 84 2543-2549. 
Hoggard N, Hunter L, Duncan JS, Williams LM, Trayhurn P \& Mercer JG 1997 Leptin and leptin receptor mRNA and protein expression in the murine fetus and placenta. PNAS 94 11073-11078.

Jaquet D, Leger J, Levy-Marchal C, Oury JF \& Czernichow P 1998 Ontogeny of leptin in human fetuses and newborns: effect of intrauterine growth retardation on serum leptin concentrations. Journal of Clinical Endocrinology and Metabolism 83 1243-1246.

Kamohara S, Burcelin R, Halaas JL, Friedman JM \& Charron MJ 1997 Acute stimulation of glucose metabolism in mice by leptin treatment. Nature 389 374-377.

Kolaczynski JW, Ohannesian JP, Considine RV, Marco CC \& Caro JF 1996 Response of leptin to short-term and prolonged overfeeding in humans. Journal of Clinical Endocrinology and Metabolism 81 4162-4165.

Maness LM, Kastin AJ, Farrell CL \& Banks WA 1998 Fate of leptin after intracerebroventricular injection into the mouse brain. Endocrinology 139 4556-4562.

McMillen IC, Phillips ID, Boss JT, Robinson JS \& Owens JA 1995 Chronic stress - the key to parturition. Reproduction, Fertility, and Development 7 499-507.

Mollanji R, Papaicocomou C, Boulton M, Midha R \& Johnston M 2001 Comparison of cerebrospinal fluid transport in fetal and adult sheep. American Journal of Physiology 281 R1215-1223.

Morrison CD, Daniel JA, Holmberg BJ, Djiane J, Raver N, Gertler A \& Keisler DH 2001 Central infusion of leptin into well-fed and undernourished ewe lambs: effects on feed intake and serum concentrations of growth hormone and luteinizing hormone. Journal of Endocrinology 168 317-324.

Nagatani S, Zeng Y, Keisler DH, Foster DL \& Jaffe CA 2000 Leptin regulates pulsatile luteinizing hormone and growth hormone secretion in the sheep. Endocrinology 141 3965-3975.

Norman LJ, Lye SJ, Wlodek ME \& Challis JRG 1985 Changes in pituitary responses to synthetic ovine corticotrophin releasing factor in fetal sheep. Canadian Journal of Physiology and Pharmacology 63 1398-1403.

Ogawa Y, Masuzaki H, Hosada K, Aizawa-Abe M, Suga J, Suda M, Ebihara K, Iwai H, Matsuoka N, Satoh N, Odaka H, Kasuga H, Fujisawa Y, Inoue G, Nishimura H, Yoshimasa Y \& Nakao K 1999 Increased glucose metabolism and insulin sensitivity in transgenic skinny mice overexpressing leptin. Diabetes $\mathbf{4 8}$ $1822-1829$.

Ott WJ 1993 Intrauterine growth retardation and preterm delivery. American Journal of Obstetrics and Gynecology 168 1710-1715.

Philipps AF, Carson BS, Meschia G \& Battaglia FC 1978 Insulin secretion in fetal and newborn sheep. American Journal of Physiology 235 E467-E474.

Ramsey JJ, Kemnitz JW, Colman RJ, Cunningham D \& Swick AG 1998 Different central and peripheral responses to leptin in rhesus monkeys: brain transport may be limited. Journal of Clinical Endocrinology and Metabolism 83 3230-3235.

Roberts TJ, Nijland MJ, Caston-Balderrama A \& Ross MG 2001 Central leptin stimulates ingestive behaviour and urine flow in the near term ovine fetus. Hormone and Metabolism Research 33 144-150.
Rosenbaum M, Leibel RL \& Hirsch J 1997 Obesity. New England Journal of Medicine 337 397-407.

Russell CD, Petersen RN, Rao SP, Ricci MR, Prasad A, Zhang Y, Brolin RE \& Fried SK 1998 Leptin expression in adipose tissue from obese humans: depot-specific regulation by insulin and dexamethasone. American Journal of Physiology 275 E507-E515.

Schneider H 1996 Ontogenic changes in the nutritive function of the placenta. Placenta 17 15-27.

Shimomura I, Hammer RE, Ikemoto S, Brown MS \& Goldstein JL 1999 Leptin reverses insulin resistance and diabetes mellitus in mice with congenital lipodystrophy. Nature 401 73-76.

Silver M 1990 Prenatal maturation, the timing of birth and how it may be regulated in domestic animals. Experimental Physiology $\mathbf{7 5}$ 285-307.

Skinner DC, Malpaux B, Delaleu B \& Caraty A 1995 Luteinizing hormone (LH)-releasing hormone in third ventricular cerebrospinal fluid of the ewe: correlation with LH pulses and LH surge. Endocrinology 136 3230-3237.

Solano JM \& Jacobson L 1999 Glucocorticoids reverse leptin effects on food intake and bodyweight without increasing NPY mRNA. American Journal of Physiology 277 E708-E716.

Stephenson T, Budge H, Mostyn A, Pearce S, Webb R \& Symonds M 2001 Fetal and neonatal adipose maturation: a primary site of cytokine and cytokine-receptor action. Biochemical Society Transactions 29 80-85.

Stevens D, Alexander G \& Bell AW 1990 Effect of prolonged glucose infusion into fetal sheep on body growth, fat deposition and gestation length. Journal of Developmental Physiology 13 277-281.

Sweeney G, Keen J, Somwar R, Konrad D, Garg R \& Klip A 2001 High leptin levels acutely inhibit insulin-stimulated glucose uptake without affecting glucose transporter 4 translocation in L6 rat skeletal muscle cells. Endocrinology 142 4806-4812.

Thomas L, Wallace JM, Aitken RP, Mercer JG, Trayhurn P \& Hoggard N 2001 Circulating leptin concentrations during ovine pregnancy in relation to maternal nutrition, body composition and pregnancy outcome. Journal of Endocrinology 169 465-476.

Vatnick I, Schoknecht PA, Darringrand R \& Bell AW 1991 Growth and metabolism of the placenta after unilateral fetectomy in twin pregnant ewes. Journal of Developmental Physiology 15 351-356.

Wooldridge JE, Anderson CM \& Perry MC 2001 Corticosteroids in advanced cancer. Oncology 15 225-234.

Yaspelkis BB, Davis JR, Saberi M, Smith TL, Jazayeri R, Singh M, Fernandez V, Trevino B, Chinookoswong N, Wang J, Shi ZQ \& Levin N 2001 Leptin administration improves skeletal muscle insulin responsiveness in diet-induced insulin-resistant rats. American Journal of Physiology 280 E130-E142.

Yuen BS, McMillen IC, Symonds ME \& Owens PC 1999 Abundance of leptin mRNA in fetal adipose tissue is related to fetal body weight. Journal of Endocrinology 163 R11-R14.

Received in final form 8 April 2002

Accepted 16 April 2002 